\title{
Fish Diversity at Pancheshwar Multipurpose Project Area in Mahakali River
}

\author{
Tej B. Saund ${ }^{1}$, Jham B. Thapa ${ }^{2}$ and Harish P. Bhatt ${ }^{2}$ \\ ${ }^{1}$ Pancheswar Multipurpose Project \\ Anamnagar, Kathmandu \\ ${ }^{2}$ Central Department of Environmental Science \\ Tribhuvan University, Kirtipur, Kathmandu \\ e-mail:saudtej@gmail.com
}

\begin{abstract}
A study was carried out to prepare a baseline information on water quality and freshwater fish diversity at Pancheshwar Multipurpose Project area in Mahakali river. The study was conducted in autumn (October 2008) and summer (June 2009). A total of 24 fish species belonging to 3 orders, 4 families and 13 genera were recorded during the investigation period. Cypriniformes was the most dominant order accounting $75 \%$ of total fish species. Siluriformes and Synbranchiformes accounted for $21 \%$ and $4 \%$ of fish species composition respectively. Spawning and rearing areas in study sites were evenly distributed providing a suitable habitat for both cold and warm water fish species. The water quality parameters, i.e., water temperature $\left(20.50-22.63{ }^{\circ} \mathrm{C}\right), \mathrm{DO}(8.58-11.85 \mathrm{mg} / \mathrm{l}) \mathrm{and} \mathrm{pH}$ (6.93-7.20) were found within the suitable range supporting diverse fish species.
\end{abstract}

Key words: fish diversity, fish habitat, water quality parameters

\section{Introduction}

Nepal, a Himalayan country, is well known for its running and standing waters which support about 200 species of fish, which are described from the Himalayan drainage system of Nepal (Shrestha 1995). Shrestha (2001) recorded 182 indigenous fish species from Nepal. Shrestha (2003) studied the fishes of Nepal from their recent taxonomic point of view and reported 186 species. Ng (2006) has listed 6 new species and 11 new records from Nepal which further increased the total number of fish species of Nepal. Rajbansi (2005) prepared a checklist from the published literature and reported 187 species, while Saund and Shrestha (2007) reported 199 species. Similarly, Shrestha (2008) reported 217 indigenous fish species from Nepal.

The vicarious habitat changes in many river systems of Nepal have caused a precipitous decline of native game fish stock and ornamental fish stock (Shrestha 1990). Numbers of many game fishes such as Mahseer (Tor tor \& T. putitora) and Copper Mahseer (Neolissochilus hexagonolepis) are declining due to barrier effects of dam, water quality changes, erratic flow fluctuations in water levels and destruction of spawning beds (Shrestha 1997).
The Mahakali river where the present study area is located harbours a variety of fishes comprising 69 species (Shrestha 1990). Shrestha (1992) reported 71 fish species in the Mahakali river system. According to Shrestha (2002), fish species in danger of extinction in Mahakali river include Tor putitora (Mahaseer), while the threatened species are Schizothorax richadsonii (Spotted snow trout), Schizothoraichthys esocinus (Mountain trout) and S. progastus (Pointsnouted snow trout). Similarly, a preliminary study on fish and fisheries in Pancheshwar High Dam and upstream areas reported 15 major species of fish in Mahakali river. Among them, 3 species (i.e., Tor tor, Tor pictutoria, Barilus jalkapoori) were long-distant migratory species, 3 species (i.e., Accrossochieilus hexagonolepis, Schizothorax plagiostomos and Schizothorax progastus) were short distance migratory species and the remaining 9 species were resident species (PACO 1991). The present study also intended to assess fish diversity, habitat and water quality in Mahakali river focusing on different components of Pancheswar Multipurpose Project (PMP). The findings from the study will benefit the planning and management of sustainable fisheries and conservation of natural resources at national level. 


\section{Study area}

Mahakali river is a perennial, torrential river at its upper headwater. The river bed is rocky and sandy with a poor algal growth (Shrestha 1990). The proposed PMP is a Nepal-India bi-national scheme on Mahakali river that forms the international border between Nepal and India. The project has been identified as a huge storage scheme to maximize power benefits of 6,720 MW peak power from 315 m high Pancheshwar High Dam and 83 m high Rupali Gad Re-regulating Dam with an annual average energy production of 12,333 GWh. The additional power generation potential of $158 \mathrm{~m}$ high Poornagiri Re-regulating Dam is estimated to be 1000 MW (DPR 1995). These proposed dams of PMP across the river will create substantial changes on the river habitat and block the migratory route of various fish species. The project area lies between $29^{\circ} 07^{\prime} 30^{\prime \prime}$ and $29^{\circ} 48^{\prime}$ North latitude and $79^{\circ} 55^{\prime}$ and $80^{\circ} 35^{\prime}$ East longitude in the Mahakali zone of the Far Western Development Region of Nepal covering some parts of Darchula, Baitadi and Dadeldhura districts (Fig. 1).

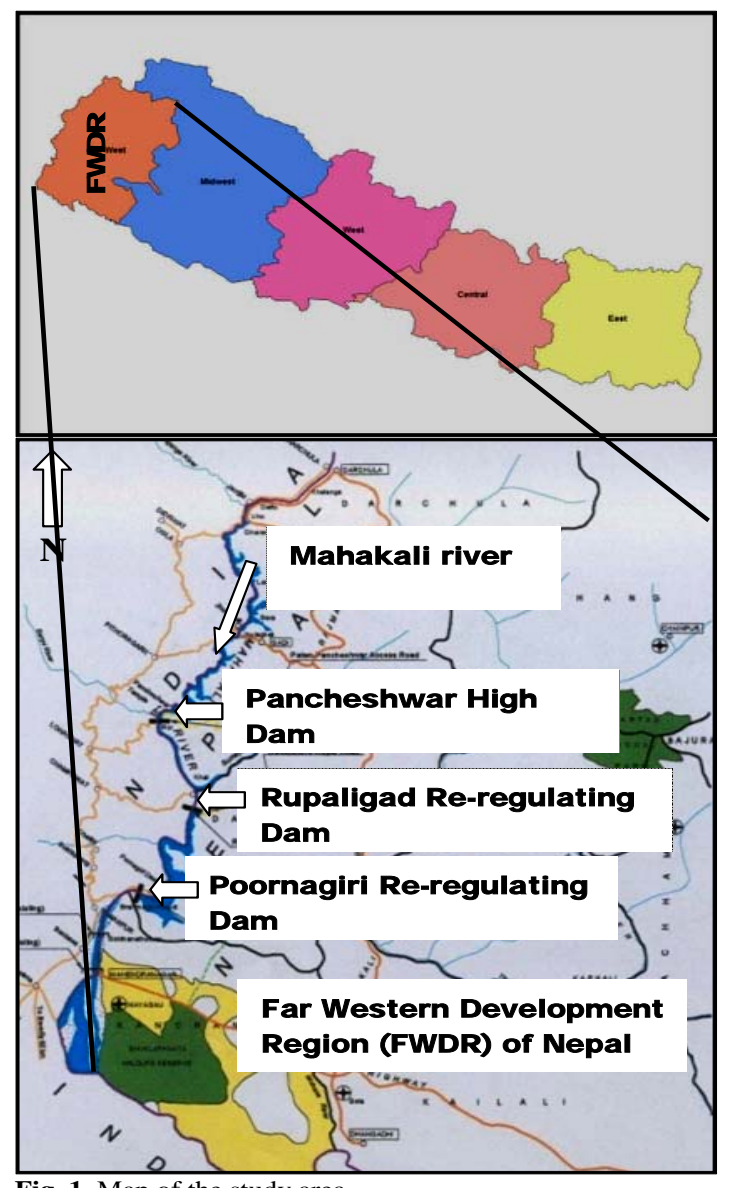

Fig. 1. Map of the study area

\section{Methodology}

Sampling sites and time schedule of the study

Three sampling sites (i.e., Pancheshwar High Dam areaI, Rupaligad Re-regulation Dam area-II and Poornagiri Re-regulating Dam area-III) were selected considering three components of Pancheshwar Multipurpose Project. The study was conducted in Mahakali river in autumn (October 2008) and summer (June 2009).

\section{Site I: Pancheshwar high dam area}

The proposed Pancheshwar High Dam on Mahakali river is located $2.5 \mathrm{~km}$ downstream from the confluence of Saryu river with Mahakali river at Pancheshwar Village Development Committee (VDC) of Baitadi District. This sampling site ranges from $426 \mathrm{msl}$ (Site office of PMP) to 435 msl (Confluence of Saryu river and Mahakali river).

\section{Site II: Rupaligad re-regulation dam area}

The proposed Rupaligad Re-regulating Dam across Mahakali river is located at $25 \mathrm{~km}$ downstream of Pancheshwar High Dam near Rupal VDC and about 300m downstream from the confluence of Rupaligad, in Dadeldhura district. The site ranges from 396 msl (1 km downstream from Rupalgad confluence to Mahakali river) to $407 \mathrm{msl}$ (1 km upstream from Rupaligad confluence to Mahakali river).

\section{Site III: Poornagiri re-regulating dam area}

Poornagiri Re-regulating Dam on Mahakali river is proposed near Jogbudha VDC, which is situated at $64 \mathrm{~km}$ downstream of Pancheshwar High Dam and about $7 \mathrm{~km}$ downstream from the confluence of Rangoon khola with Mahakali river in Dadeldhura district. There is no settlement at the proposed dam site however Karali settlement is located about 1 $\mathrm{km}$ upstream from the dam site. The sampling site ranges from $295 \mathrm{msl}$ (1 km downstream from Karali khola confluence to Mahakali river) to $305 \mathrm{msl}$ (1 km upstream Karali khola confluence to Mahakali river).

\section{Fish sampling}

Cast net was mostly used to collect the fish during field visit from each site. However, gill net and other local techniques were also used. Trained local fishermen were hired for this purpose. Fish species available at the local market and caught by local fishermen were also purchased.

Information on local name and behaviour pattern was obtained from fishermen. Fish species collected during the field survey were noted and excess fishes were released to their original habitat. The collected fish species were preserved in $8-10 \%$ 
Tej B. Saund et al./Fish Diversity at Pancheshwar.....

formaldehyde solution for further study. They were identified using standard method of Talwar and Jhingran (1991), Jayaram (1999) and Shrestha (1981, 1994).

Table 1. Fish species recorded at sampling sites

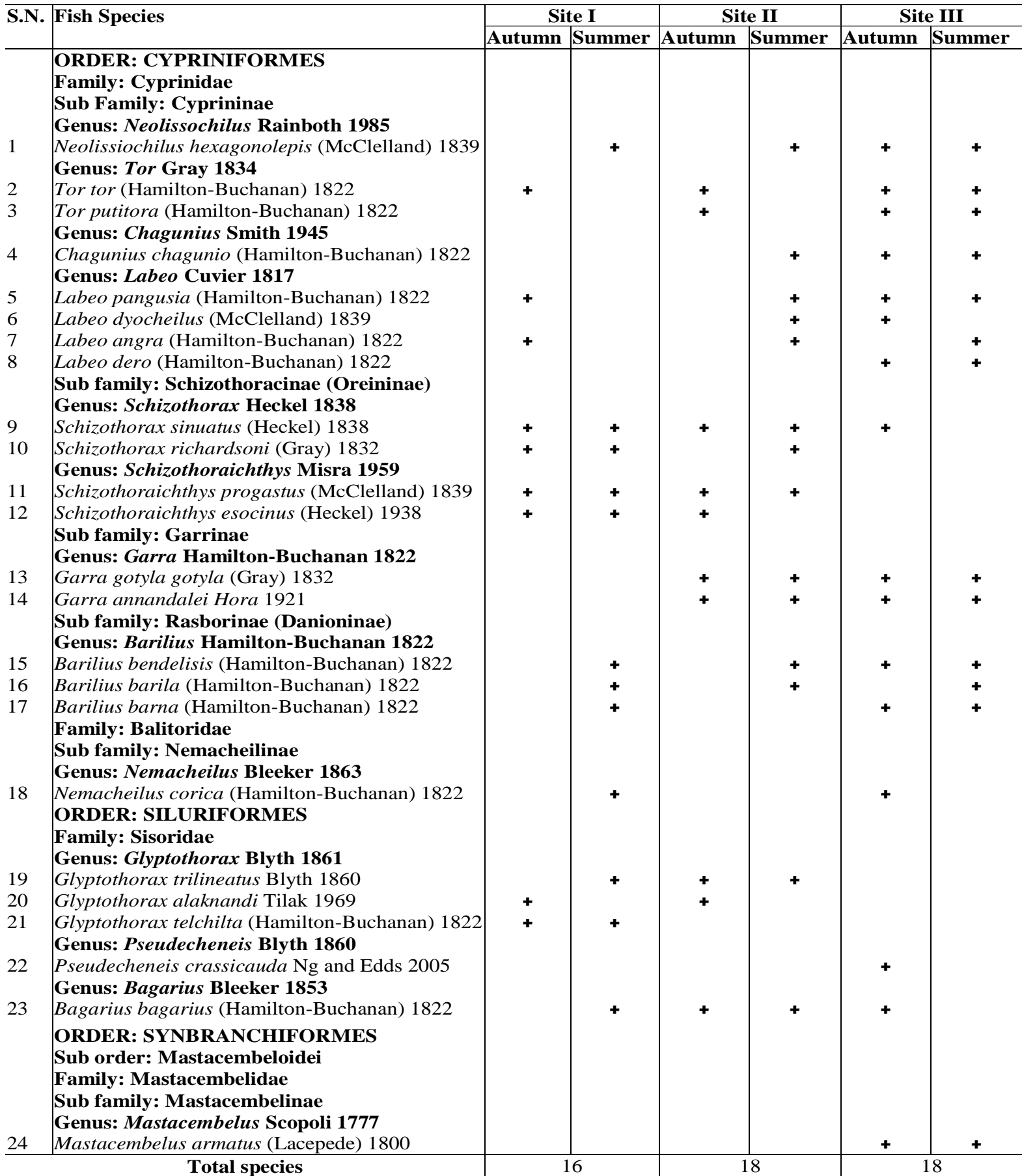

\section{Water quality analysis}

Physico-chemical analysis of water was conducted to determine the water quality of the river. Portable water analysis kit (Hach Chemical CO. Ames., Iowa, USA; 
Model: Dr. el/2) was used to analyze temperature, DO and $\mathrm{pH}$ of water in situ condition in the field following the standard methods prescribed by APHA (1976).

\section{Results and Discussion}

\section{Fish diversity}

Altogether 24 fish species belonging to 3 orders (i.e., Cypriniformes, Siluriformes and Synbranchiformes), 4 families (i.e., Cyprinidae, Balitoridae, Sisoridae and Mastacembelidae) and 13 genera (i.e., Neolissochilus, Tor, Chagunius, Labeo, Schizothorax, Schizothoraichthys, Garra, Barilius, Nemacheilus, Glyptothorax, Pseudecheneis, Bagarius, Mastacembelus) were recorded from the study area (Table 1).

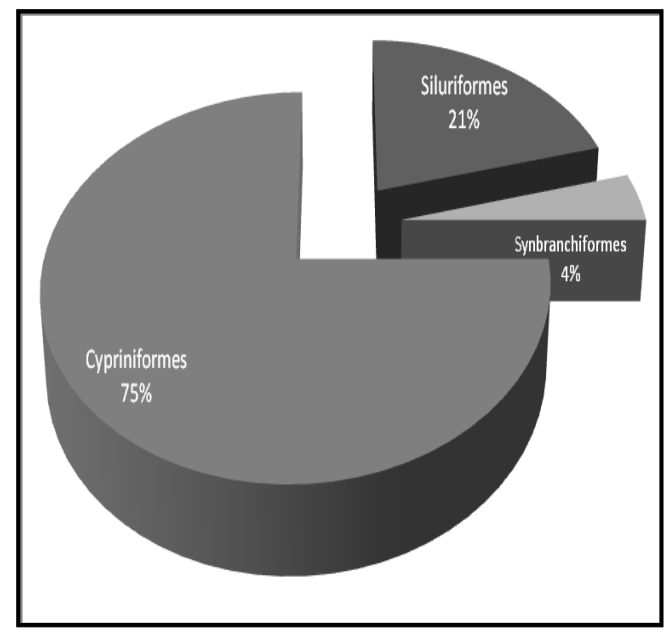

Fig. 2. Composition of collected fish

Based on field observation \& information from local fishermen, fish species like Tor sp., Labeo sp., Bagarius bagarius were observed in deep water area. The species such as Schizothorax sp., Garra sp., Glyptothorax sp. and Neolissocheilus hexagonolepis were recorded in fast flowing and running water.

Fish species such as Labeo sp., Bagarius bagarius, Barilius sp. and Neolissocheilus hexagonolepis which are also known for warm water species were found at upstream of Pancheshwar High Dam area during summer when the water temperature exceeded 20ÚC. This indicates that these fishes migrate to upstream only for grazing purpose when the water temperature is favorable for them. Besides, some steeper gradient above the Rupaligad Dam area, most of the area possesses gentle gradient with suitable habitat for fish species. The region above Poornagiri Dam area has a gentle gradient, relatively low velocity, plenty of boulder, pebble, gravel, sand, pool and backwater providing favorable condition for rearing and grazing.

\section{Spawning and rearing area}

Field observations reveal that the Mahakali river and its tributaries have boulder, pebble, gravel, sand, riffles, pools \& backwaters in some places, provide appropriate spots for spawning and rearing grounds for diverse fish species. The evenly distributed spawning and rearing sites were observed at both sides of the river. However, the deep pools near the confluence point of Rupaligad and Mahakali river were found to be more suitable for feeding rather than spawning area. Comparatively, upper reaches of study area possesses medium spawning and rearing area. On the other hand, confluence of Karali khola and upstream from Poornagiri Dam area were observed as productive habitats having maximum spawning and rearing areas (Table 2).

\section{Water quality analysis}

The mean values of water quality parameters are presented in Table 3.

Table 2. Spawning and rearing areas at different sampling sites

\begin{tabular}{l|l|c|c}
\hline \multicolumn{1}{|c|}{ Study site } & Spawning area & Rearing area \\
\hline I & \multicolumn{1}{|c}{} & \\
1 & Pancheshwar High Dam area & $\mathbf{+}$ \\
2 & Confluence of Saryu river \& Mahakali & $\mathbf{+ +}$ & $\mathbf{+ +}$ \\
3 & Pancheswar Dam area & $\mathbf{+ +}$ \\
II & Downstream from Pancheswar Dam area & & $\mathbf{+ +}$ \\
1 & Rupaligad Re-regulation Dam area & & $\mathbf{+}$ \\
2 & Upstream of Rupaligad Dam area & $\mathbf{+ +}$ & $\mathbf{+ +}$ \\
3 & Rupaligad Dam area & $\mathbf{+ +}$ \\
III & Downstream from Rupaligad Dam area & $\mathbf{+ +}$ & $\mathbf{+ +}$ \\
1 & Poornagiri Re-regulation Dam area & & $\mathbf{+ +}$ \\
2 & Upstream from Karali confluence area & $\mathbf{+ +}$ & $\mathbf{+ +}$ \\
3 & Karali khola confluence area & $\mathbf{+ +}$ & $\mathbf{+ + +}$ \\
\hline
\end{tabular}

+= Low; ++ = Moderate; +++ = Maximum 
Tej B. Saund et al./Fish Diversity at Pancheshwar....

Table 3. Water quality of the study area

\begin{tabular}{l|l|l|l} 
Parameters & $\begin{array}{l}\text { Pancheshwar } \\
\text { Dam area }\end{array}$ & $\begin{array}{l}\text { Rup aligad } \\
\text { Dam area }\end{array}$ & $\begin{array}{l}\text { Poornagiri } \\
\text { Dam area }\end{array}$ \\
Water temp. ("C) & $20.50 \pm 2.04$ & $20.88 \pm 1.75$ & $22.63 \pm 1.00$ \\
pH & $7.20 \pm 0.57$ & $693 \pm 0.51$ & $7.20 \pm 0.68$ \\
DO (mglit.) & $8.58 \pm 0.90$ & $11.85 \pm 1.91$ & $9.0 \pm 1.03$ \\
\hline
\end{tabular}

The average water temperature ranged from 20.50 to $22.63^{\circ} \mathrm{C}$. Temperature in the range 20 to $32^{\circ} \mathrm{C}$ is ideal for majority of freshwater fishes (Boy 1990). Natural bodies of water may exhibit a seasonal and diurnal variation and is closely related with the change in atmospheric temperature (Kundanagar et al. 1996).

The average $\mathrm{pH}$ value varied from 6.93 to 7.20. Generally low $\mathrm{pH}$ value is harmful to fishes. Water having $\mathrm{pH}$ value below than 5.0 and above 9.5 are not suitable (APHA 1976). The $\mathrm{pH}$ is considered as a measure of environmental suitability and a range of 7.0 to 8.5 is considered to support a rich biota and fish (Bell 1971).

The average dissolved oxygen ranged from 8.58 to $11.85 \mathrm{mg} / \mathrm{l}$. Dissolved oxygen above $5 \mathrm{mg} / \mathrm{l}$ is suitable for the support of diverse biota (APHA 1976). Lower oxygen concentration kills the fish and other organisms that are present in the water. $\mathrm{DO}>5 \mathrm{mg} / \mathrm{l}$ is considered favorable for growth and activity of most aquatic organisms; DO $<3 \mathrm{mg} / \mathrm{l}$ is stressful to most aquatic organisms, while DO $<2 \mathrm{mg} / \mathrm{l}$ does not support fish life (USEPA 2000).

The physical and chemical characteristics of water bodies affect the species composition, abundance, productivity and physiological conditions of aquatic organisms (Bagenal 1978).

Twenty four freshwater fish species were recorded from different sampling sites of Pancheshwar Multipurpose Project area during the investigation period. Evenly distributed spawning and rearing area of sampling site provides a suitable habitat for both cold and warm water fish species. The controlling factors $(\mathrm{pH}$, temperature and $\mathrm{DO})$ were within the suitable range to support good fish production.

Appropriate numbers of fish hatcheries should be developed in the possible area of the project to minimize the impact of dams on fish population. The fishlings thus produced should be left towards the upstream of dams on regular basis. Similarly, riverine ecology should be maintained by releasing at least $10 \%$ of water for downstream of each dams.

Further and in-depth studies at all seasons on migratory ecology with fish behavior \& habitat should be carried out in Detailed Environmental Management Plan (DEMP) of PMP so that finding may be directly applied for the conservation of native species. Potentiality of cage fish culture of indigenous fishes in the reservoir should also be analyzed thoroughly in DEMP.

\section{Acknowledgements}

Authors are very thankful to Pancheshwar Multipurpose Project for encouragement, suggestions and valuable literatures supported to this research work. We also thank Prof. Dr. Jiwan Shrestha, Mr. Nabin Bahadur Bam, Mr. Bisnu Bahadur Silwal and Mr. Janak Saud for their help during field survey and lab work.

\section{References}

American Public Health Association (APHA). 1976. Standard methods for the examination of water \& waste water. American Public Health Association, Washington D.C.

Bagenal, T. B. 1978. Fecundity in eggs and early life history ( $3^{\text {rd }}$ edition). (Bagenal, T.B., Braum, E. Part 1). In: Methods for assessment of fish production in fresh waters (Ed. T.B. Bagenal). pp. 166-178.

Bell, H. L. 1971. Effect of low pH on survival and emergence of aquatic insects. Water Resource 5:313

Boyd, C.E. 1990. Water quality in ponds for qquaculture. Birmingham Publishing Company, Birmingham, Alabama.

DPR 1995. Detailed Project Report of Pancheshwar Multipurpose Project. Electricity Development Center, HMG, Kathmandu, Nepal. Vol. 1, Executive Summary, Section 1.

Gautam, D., T.B. Saund and J. Shrestha. 2010. Water Quality and Fish Diversity of Jagadispur Reservoir, Kapilbastu District, Nepal-a Ramsar Site. Nepal Journal of Science and Technology 11:229-234.

K.C., Jayaram. 1999. The freshwater fishes of the Indian region. Narendra Publishing house, Delhi, India. 551pp.

Kundanagar, M.R.D.,S.G. Sarwar and J. Hussain. 1996. Zooplankton population and nutrient dynamics of wetlands of Wular Lake, Kashmir, India. In: Environment and biodiversity in the context of South Asia (Eds. P. K. Jha, G. P. S. Ghimire, S. B. Karmacharya, S.R. Baral \& P. Lacoul). Ecological Society (ECOS), Nepal, pp. 128-134. 
Nepal Journal of Science and Technology Vol. 13, No. 2 (2012) 225-230

Ng, H.H. 2006. The identity of Pseudechenis sulcatus (McC lelland) with description of two new species of Rheophitic cat fish (Teleostei: Sissoridae). Zootaxa 1254:45-68.

PACO. 1991. Field investigations within Nepal territory. Additional services, Pancheshwar Consortium, Nepal.

Rajbanshi, K.G. 2005. Review on current taxonomic status and diversity of fishes in Nepal. Nepal Academy of Science and Technology. Occasional paper 10. 41pp.

Saund, T.B. and J. Shrestha. 2007. Fish and benthic fauna in Kulekhani Reservoir. Nepal Journal of Science and Technology 8:63-68.

Shrestha, J. 1981. Fishes of Nepal. Curriculum Development Centre, Tribhuvan University, Kathmandu, Nepal. 318 pp.

Shrestha, J. 1994. Fishes, Fishing Implements and Method of Nepal. Published by: Smt. M.D. Gupta, Lalitpur Colony, Lashkar (Gwalior), India.

Shrestha, J. 2001. Taxonomic revision of fishes of Nepal. In: Biodiversity, agriculture and pollution in South Asia (Eds. P.K. Jha et al.). ECOS, Kathmandu, pp. 171-180.

Shrestha, J. 2003. Taxonomic revision of fishes of Nepal. In: Cold water fisheries in the trans-Himalayan countries. FAO Fisheries technical paper No.431. pp. 273-288.

Shrestha, J., D.M. Singh and T.B. Saund. 2009. Fish diversity of Tamor River and its major tributaries of Eastern Himalayan Region of Nepal. Nepal Journal of Science and Technology 10:219-223.
Shrestha, T.K. 2002. Ranching Mahseer (Tor tor, Tor puttitora in the running water of Nepal). In: Cold Water Fisheries in the Trans-Himalayan Countries. (Eds. T. Petr \& D.B. Swar) FAO Fisheries Technical Paper 431, Rome, Italy.

Shrestha, T.K. 1990. Resource ecology of the Himalayan waters. Curriculum Development Centre, Tribhuvan University, Nepal. pp. 61-109.

Shrestha, T.K. 1992. Propagation of Mahseer in the Himalayan Waters of Nepal. In: National Research Council 1992 Aquaculture and Schistomiasis: Proceeding of a Network meeting held in Manila, Philippines (August 6-16: 61-78), National Academy Press, Washington DC.

Shrestha, T.K. 1995. Fish catching in the Himalayan waters of Nepal. B. Shrestha, Kathmandu, Nepal. 247 pp.

Shrestha, T.K. 1997. The Mahseer in the rivers of Nepal disrupted by dams and Ranching Strategies. B. Shrestha, Kathmandu, Nepal. 259 pp.

Shrestha, T.K. 2008. Ichthyology of Nepal. A study of fishes of the Himalayan waters. Himalayan Ecosphere. Kathmandu, Nepal. pp.1- 388.

Talwar, P.K. and A.G. Jhingran. 1991. Inland fishes of India and adjacent countries. Vol. I \& II. Oxford and IBH publishing Co. Pvt. Ltd., New Delhi, India.

United States Environmental Protection Agency (USEPA). 2000. Aquatic life criteria for dissolved oxygen, Washington, DC. 